\title{
The origin of urinary aromatic compounds excreted by ruminants
}

\author{
4. The potential use of urine aromatic acid and phenol outputs as a measure of \\ voluntary food intake
}

\author{
BY A. K. MARTIN \\ Hannah Research Institute, Ayr KA6 5HL, Scotland \\ AND J. A. MILNE AND P. MOBERLY \\ Hill Farming Research Orğanization, Penicuik, Midlothian EH26 OPH, Scotland
}

(Received 22 February 1982 - Accepted 13 July 1982)

1. Studies were made of the extent to which $p$-cresol, catechol, quinol and orcinol infused through rumen or abomasal cannulas to sheep were recovered in their urine.

2. Rumen fermentation of dietary phenolic compounds caused the excretion of simple phenols in the urine. In decreasing order of magnitude these were: $p$-cresol, catechol, phenol and 4-methylcatechol with only traces of quinol and orcinol

3. The percentages of rumen-infused $p$-cresol or orcinol recovered as increments in the urinary phenol outputs of sheep ( 94 and $99 \%$ respectively) following infusion showed that rumen degradation of these phenols was negligible.

4. After rumen infusion of catechol and quinol, mean recoveries of these phenols in urine were only 55 and $77 \%$ respectively. Possible reasons for these incomplete recoveries are discussed.

5. Studies were also made of the use of the urinary phenol output of phenols characteristic of particular forages as indices of their voluntary intake by sheep. Calluna vulgaris $\mathrm{L}$. (Hull) (heather) may contain $1300-3600 \mathrm{mg} / \mathrm{kg}$ dry matter (DM) of orcinol and $200-800 \mathrm{mg} / \mathrm{kg}$ DM of quinol as $\beta$-glycosides. When heather was offered ad lih. to sheep given one of five levels of grass, linear relationships were found between heather intake and urinary quinol and orcinol outputs.

6. The urinary output of aromatic acids was also determined when sheep ate grass and heather. Urinary phenylacetic acid output was linearly related to grass but not to heather intake. The relationship between urinary phenylacetic acid output and grass intake could vary with different forages but that between orcinol output and heather intake was considered a useful index of heather intake.

7. Methods for the assay of urine phenols are discussed.

As appropriately-substituted, naturally-occurring phenolic acids are known to be extensively decarboxylated to simple phenols by intestinal micro-organisms (Scheline, 1978), microbial fermentation of food in the rumen would be expected to lead to significant production of phenols. Studies in this laboratory (Martin, 1982c) have confirmed the relatively large urinary output of some phenols by sheep. When compared to the urinary output of normal healthy men, sheep excreted approximately seven times more p-cresol (Duran et al. 1973) and twenty times more catechol (Smith, 1961). Sheep also excreted small amounts of 4-methylcatechol, phenol and p-ethylphenol.

Simple phenols and their conjugates are uncommon in plants (Harborne \& Simmonds, 1964) and are seldom found in those used as ruminant foods, although phenols do accumulate in ensiled forages during fermentation (Clarke \& Humphreys, 1971; Kibe \& Kagura, 1976; Sakata \& Ishiyama, 1978).

Little is known of the fate of phenols in the rumen. Studies of the anaerobic metabolism of phenols by cultures of intestinal micro-organisms have shown that after adaptation, usually over a period of 1 or 2 months, the aromatic ring of most simple, naturally-occurring phenols can be completely degraded. Thus, anaerobic methamogenic cultures can completely degrade the aromatic ring of catechol via cis-benzenediol (Balba \& Evans, 1980). In contrast 
unadapted cultures of rumen micro-organisms were unable to utilize catechol, phenol, quinol, orcinol or resorcinol, although phloroglucinol was rapidly degraded (Tsai et al. 1976) to acetate and carbon dioxide.

The presently reported studies were made to investigate phenol metabolism in sheep and to study the possibility of using the urinary output of phenols characteristic of a moorland plant, Calluna vulgaris L. (Hull) (heather), to assess the voluntary intake of this plant by grazing sheep. The results obtained showed that $p$-cresol and orcinol (3,5-dihydroxytoluene) are completely excreted in the urine of sheep and that recoveries of quinol were almost complete. The results suggest that the urinary output of orcinol by sheep could be a useful index of heather intake.

\section{EXPERIMENTAL}

Animals

The wether sheep of between 1 and 4 years of age used in these experiments were: Expt 1, two rumen-cannulated Cheviot sheep, nos. 5 and 6; Expt 2, three rumen-cannulated Cheviot sheep, nos. 13, 14 and 15 and one abomasally-cannulated sheep no. 16; Expt 3, twenty-five 2-year-old Scottish Blackface sheep.

\section{Experiments and rations}

Expt 1. Barn-dried hay containing 193 g crude protein (nitrogen $\times 6 \cdot 25$ ) $/ \mathrm{kg}$ dry matter (DM) was offered to sheep at two feeding levels in a change-over experiment in which phenols were infused via rumen cannulas to sheep given both a low $(\mathrm{L}, 0.43 \mathrm{~kg} \mathrm{DM} / \mathrm{d})$ and high $(\mathrm{H}, 0.86 \mathrm{~kg} \mathrm{DM} / \mathrm{d})$ level of hay intake. Individual phenol infusions were made in which $p$-cresol $(1000 \mathrm{mg} / \mathrm{d})$, catechol $(500 \mathrm{mg} / \mathrm{d})$, quinol $(300 \mathrm{mg} / \mathrm{d})$ and orcinol $(300 \mathrm{mg} / \mathrm{d})$ were administered to each sheep at each level of feeding.

Expt 2. Sheep were given a ration of hay $(0.52 \mathrm{~kg} \mathrm{DM} / \mathrm{d})$ and a concentrate mixture $(186 \mathrm{~g}$ crude protein $/ \mathrm{kg} \mathrm{DM}$ ) made up of cooked flaked maize, bean meal, decorticated cotton cake and rolled oats in the proportions $4: 7: 7: 11$ by weight $(0.51 \mathrm{~kg} \mathrm{DM} / \mathrm{d})$. Different levels of quinol $(100-500 \mathrm{mg} / \mathrm{d})$ and of orcinol $(10-250 \mathrm{mg} / \mathrm{d})$ were infused through rumen or abomasal cannulas.

In Expts 1 and 2 food was given in two equal portions daily at 09.00 and 16.30 hours. Water was freely available at all times. Sheep were maintained on these diets for at least 2 weeks before the start of the experiments.

Expt 3. Grass and heather were harvested in September and immediately frozen in a cold store $\left(-20^{\circ}\right)$. The grass was regrowth from a mixed sward (principally perennial ryegrass (Lolium perenne L.) and the heather was the current season's shoots from a 'building' stand of heather. Five levels of grass $(\mathrm{kg} \mathrm{DM} / \mathrm{d} ; 0,0 \cdot 2,0.4,0.6,0.8)$ were offered to groups of five sheep at each level of intake at 09.00 hours daily. At 13.00 hours heather was offered ad lib. Refusals were collected daily at 09.00 hours and DM intakes of grass and heather determined.

Collection of faeces and urine. Sheep were harnessed for faeces and urine collection and urine collected at $\mathrm{pH} 4$ as described previously (Martin, 1982a).

\section{Experimental procedures}

Expt 1. Throughout the experiment an infusion of a saline solution (for composition, see Martin, 1982a) was made as a continuous drip into the rumen at a rate of $21 / \mathrm{d}$. Experimental periods were of $7 \mathrm{~d}$ duration and urine collections were sampled on days 4-7 inclusive. Control periods in which only saline was infused alternated with experimental periods in which individual phenols were dissolved in the saline.

Expt 2. In this experiment a saline solution was also infused as a continuous drip into 
the rumen or abomasum of sheep but at a reduced rate of $0.8 \mathrm{l} / \mathrm{d}$. The duration of experimental periods and days of sampling were as in Expt 1. The phenols infused in this experiment were found only in trace quantities in urine so control saline infusions were made only at the start and end of the experiment.

Expt 3. Experimental periods were of $28 \mathrm{~d}$ duration and urine collections sampled on days 18-28 inclusive of each period.

In all experiments urine assays, other than of creatinine, were made on a composite sample prepared by mixing a fixed proportion of individual daily urine samples. These samples were stored at $-20^{\circ}$ until required for analysis.

Analysis of infused solutions. In Expts 1 and 2 the amounts of phenol infused daily were determined by weighing the quantity infused, determining the specific gravity of a sample and the concentration of the phenol in it by u.v. spectrophotometry. A suitably-diluted solution containing 50-100 $\mu \mathrm{g}$ phenol $/ \mathrm{ml}$ was placed in a $10 \mathrm{~mm}$ path-length cuvette and its absorbance determined between 320 and $220 \mathrm{~nm}$ in a Pye-Unicam SP 800 A spectrophotometer (Pye-Unicam Ltd, Cambridge). The infusion reservoirs were bubbled with a slow stream of oxygen-free nitrogen throughout the infusion periods. The molecular extinctions and absorbance maxima $\left(\lambda_{\max } ; \mathrm{nm}\right)$ of the phenols infused in dilute saline solution were respectively: $p$-cresol 1590, 277; catechol 2230, 275; quinol 2460, 288; anhydrous orcinol 1288, 273.

\section{Urine analyses}

Creatinine. In Expts 1 and 2 the creatinine content of day 1-7 urine samples inclusive was determined in all periods by the DEAE Sephadex column chromatographic method described previously (Martin, 1982a).

Titratable acids of diethylether-and toluene-soluble extracts of hydrolysed urine. In Expts 1 and 3 these acids were determined as described previously (Martin, 1982a).

Gas-liquid chromatography of the toluene-soluble acids in hydrolysed urine. In Expts 1 and 3 the aromatic acids present in these extracts were determined by chromatography of their methyl esters on $5 \%(\mathrm{w} / \mathrm{w})$ neopentylglycolsuccinate (NGS) columns at $150^{\circ}$ as described previously (Martin, 1982a).

\section{Urine phenol assay}

Hydrolysis of phenol conjugates. For enzyme hydrolyses one of two $\beta$-glucuronidase (EC 3.2.1.31)-sulphatase (EC 3.1.6.1) preparations supplied by Sigma (Poole, Dorset) were used with incubations made at pH 5 in $0.03 \mathrm{M}$ acetate buffer for $64 \mathrm{~h}$ at $39^{\circ}$.

Expt 1 . To $0.5 \%$ of the daily urine output a quantity of the type $\mathrm{H}-2$ enzyme preparation containing 1.5 i.u. $\beta$-glucuronidase and 49 i.u. sulphatase was added and the samples incubated in triplicate for $64 \mathrm{~h}$ at $39^{\circ}$.

Expt 2. Enzyme hydrolyses were made by adding to $0.5 \%$ of the daily urine output type $\mathrm{H}-1$ enzyme containing 0.5 i.u. $\beta$-glucuronidase and 25 i.u. sulphatase and incubating duplicate samples for $64 \mathrm{~h}$ at $39^{\circ}$.

Acid-hydrolyses were also made in duplicate by heating $0.5 \%$ of the daily urine output in $0.75 \mathrm{M}$-sulphuric acid for $1 \mathrm{~h}$ in stoppered tubes in a boiling water-bath.

Expt 3. Only acid-hydrolyses were made in which $1.0-2.5 \%$ of the daily urine output were hydrolysed by boiling under reflux in $0.75 \mathrm{M}-\mathrm{H}_{2} \mathrm{SO}_{4}$ for $1 \mathrm{~h}$. Duplicate hydrolyses were made.

\section{Extraction of urine phenols}

Expts 1 and 3. Hydrolysed urine samples were extracted three times with 1 vol. redistilled diethyl ether and the extracts dried over anhydrous sodium sulphate. 
Expt 2. In this experiment hydrolysed urine samples were buffered at $\mathrm{pH} 7$, extracted with redistilled diethyl ether and ethyl acetate and the combined extracts dried over oven-dried $\left(190^{\circ}\right)$ magnesium sulphate.

In all experiments $1 \mathrm{mg}$ nonadecane was added to the first solvent wash as an internal standard.

\section{Gas-liquid chromatography of urine phenols}

To the dried solvent extracts between $200 \mu \mathrm{l}$ and $2 \mathrm{ml}$ dry pyridine (or chloroform-pyridine $(9: 1, v / v)$ if solvent peak tailing proved troublesome) were added and the extraction solvents then removed in vacuo in a rotary film evaporator (Buchi Rotavapor RE; Orme Scientific Ltd, Manchester).

Derivatives for chromatography were prepared after placing extracts equivalent to between 0.05 and $0.15 \%$ of the daily urine output in a $0.3 \mathrm{ml}$ capacity 'reactivial' sealed with a 'mininert' value cap (Pierce \& Warriner Ltd, Chester). Acetate derivatives were prepared by adding 50-150 $\mu 1$ acetic anhydride, and trimethylsilyl (TMS) derivatives by adding $100 \mu \mathrm{l} \mathrm{N,O-(bistrimethylsilyl)-trifluoroacetamide} \mathrm{(BSTFA)} \mathrm{containing} 10 \mathrm{ml}$ trimethylchlorosilane (Sigma).

Expts 1 and 3. Acetates of phenols were separated in glass columns $1.52 \mathrm{~m} \times 4 \mathrm{~mm}$ (i.d.) fitted to a Pye 104 gas chromatograph (Pye Unicam Ltd). In Expt 1 the columns were packed with $3 \%$ (w/w) OV 17 on 125-149 $\mu$ m Diatomite MQ (J. J.'s Chromatography Ltd, Kings Lynn, Norfolk). The initial column oven temperature of $75^{\circ}$ was increased at $6^{\circ} / \mathrm{min}$ to $280^{\circ}$. Peak areas were measured by a Kent Chromalog II integrator (Kent Instruments, Luton, Beds.). In Expt 3 the columns were packed with $3 \%$ OV 17 on $149-177 \mu \mathrm{m}$ Chromosorb W (HP). The initial column oven temperature of $75^{\circ}$ was increased at $3^{\circ} / \mathrm{min}$ to $220^{\circ}$. Peak height ratios, phenols:internal standard were measured to determine the quantity of phenols in the sample.

Expt 3. Acetate and TMS derivatives of phenols were separated in glass columns $1.83 \mathrm{~m}$ long $\times 4 \mathrm{~mm}$ (i.d.) fitted to a Hewlett-Packard model 5710 gas chromatograph and peak areas measured using either an HP 3373 B or HP $3800 \mathrm{~A}$ integrator (Hewlett-Packard Ltd, Winnersh, Wokingham, Berks.). The columns were packed with either $10 \%(\mathrm{w} / \mathrm{w})$ OV 1 on 149-177 $\mu \mathrm{m}$ Chromosorb W (HP) (British Drug Houses, Poole, Dorset), $10 \%$ (w/w) OV 17 on 125-149 $\mu \mathrm{m}$ Diatomite MQ or (for TMS phenols only) $5 \%(\mathrm{w} / \mathrm{w})$ trixylenylphosphate (TXP) on 125-149 $\mu \mathrm{m}$ Diatomite MQ. The initial analyser oven temperature for OV 1 columns was $100^{\circ}$ and was held constant for $4 \mathrm{~min}$; for OV 17 columns the initial oven temperature was $75^{\circ}$ also held for $4 \mathrm{~min}$ and then with both columns the oven temperature was increased at $8^{\circ} / \mathrm{min}$ to $250^{\circ}$ and held for $4 \mathrm{~min}$. TXP columns were operated isothermally at $115^{\circ}$.

Gas chromatographic operating conditions not noted previously, the separation of phenol derivatives on these columns and the identification of the phenol components of the peaks found on gas-liquid chromatograms by manual-preparative gas-liquid and thin-layer chromatography and by u.v. spectrophotometry, will be described elsewhere.

\section{RESULTS}

\section{Output of urinary phenols in control periods}

Other than for quinol, higher yields of phenols were obtained following enzyme- than acid-hydrolysis. The results quoted are therefore, where possible, those obtained after enzyme hydrolyses for phenols other than quinol and those after acid-hydrolyses for quinol.

The mean weights of the sheep and their urinary creatinine and phenol outputs in Expts 1 and 2 are summarized in Table 1. Urinary phenol output increased with increasing food intake (Expt 1). The principal urinary phenol was $p$-cresol with lesser amounts of catechol 


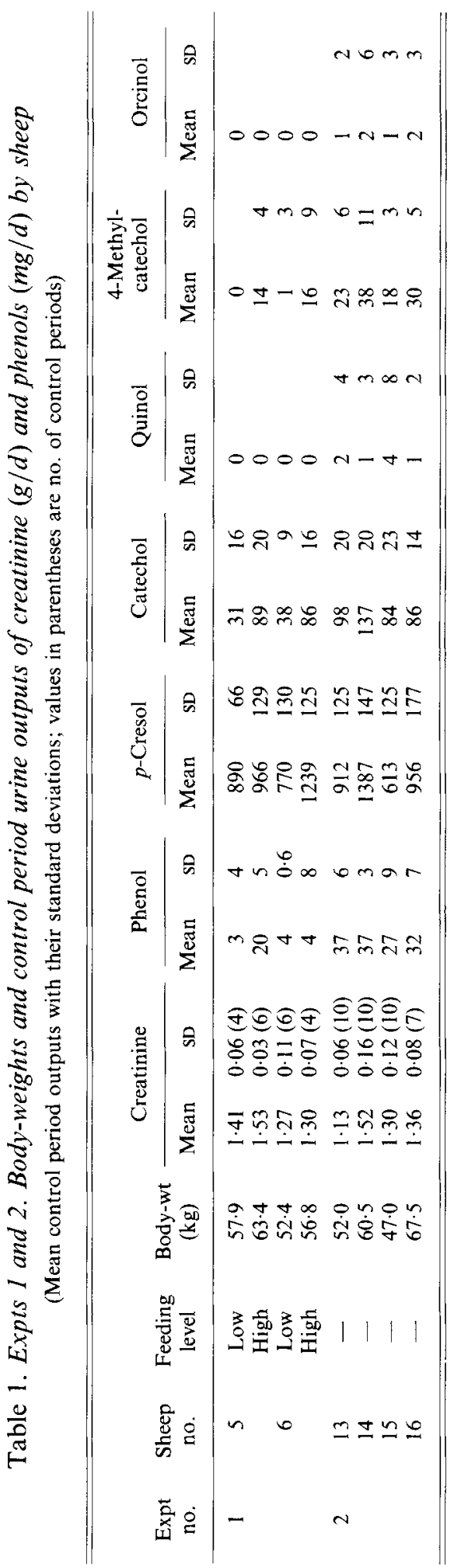


Table 2. Expt 1. Increments in urinary phenol output following phenol infusion to the rumens of sheep

(Mean values with their standard deviations; no. of infusions in parentheses)

\begin{tabular}{|c|c|c|c|c|c|c|c|}
\hline \multirow{3}{*}{$\begin{array}{l}\text { Phenol } \\
\text { infused }\end{array}$} & \multirow{3}{*}{$\begin{array}{c}\text { Sheep } \\
\text { no. }\end{array}$} & \multicolumn{6}{|c|}{ Percentage recovery in urine } \\
\hline & & \multicolumn{2}{|c|}{$\begin{array}{l}\text { Quantity } \\
\text { infused }(\mathrm{mg} / \mathrm{d})\end{array}$} & \multicolumn{2}{|c|}{ Feeding level } & \multirow[b]{2}{*}{ Mean } & \multirow[b]{2}{*}{ SD } \\
\hline & & Mean & SD & Low & High & & \\
\hline$p$-Cresol & 5,6 & 1076 & 27 & $95(2)$ & $93(2)$ & 94 & 10 \\
\hline Catechol & 5,6 & 427 & 197 & $53(2)$ & $57(2)$ & 55 & 9 \\
\hline Quinol & 5,6 & 295 & 41 & $63(2)$ & $73(2)$ & 68 & 15 \\
\hline Orcinol & 5,6 & 304 & 32 & $103(2)$ & $95(2)$ & 99 & 8 \\
\hline
\end{tabular}

and phenol always being present. 4-Methylcatechol was found in most samples but quinol and orcinol occurred in trace amounts only with the diets offered in these experiments.

\section{Calculations of increments in urine phenol output}

The daily urinary creatinine output of each sheep in each control and phenol-infusion period was determined and from these values the mean control output of phenols/g creatinine was calculated for each sheep in each experiment. The basal phenol outputs in phenol-infusion periods were calculated as the product of this value and the mean creatinine output during that period. Phenol increments were found by the difference between the observed and calculated basal phenol outputs.

\section{Recovery of rumen- or abomasum-infused phenols in the urine}

In Expt 1 four phenols were infused each at a single level to the rumens of two sheep given barn-dried hay at two feeding levels. The phenols found in extracts of enzyme-hydrolysed urine are summarized in Table 2. One catechol infusion was, in error, made at one-quarter of the intended concentration, accounting for the large variation in quantities infused (Table 2). Orcinol and $p$-cresol were completely recovered in urine but catechol $(55 \%)$ and quinol $(68 \%)$ were apparently not. Feeding level did not affect the urinary recovery of infused phenols.

Four different levels of quinol (nominally 100, 125, 250 and $500 \mathrm{mg} / \mathrm{d}$ ) and of orcinol (nominally 12,63, 125 and $250 \mathrm{mg} / \mathrm{d}$ ) were infused into three rumen- and one abomasallycannulated sheep in Expt 2. The results are shown in Table 3 . The $100 \mathrm{mg}$ quinol/d infusion was made as the quinol $\beta$-glucoside, $p$-arbutin. The urinary orcinol outputs presented are those found in extracts of enzyme-hydrolysed urine; the urinary quinol outputs, those found in extracts of acid-hydrolysed urine. In two quinol-infusion periods, acid-hydrolyses were, in error, not made (sheep no. $15,125 \mathrm{mg} / \mathrm{d}$; sheep no. $14,500 \mathrm{mg} / \mathrm{d}$ ). Sheep no. 16 refused food towards the end of the experiment and was withdrawn; in consequence only one quinol infusion was made via an abomasal cannula.

\section{Urinary aromatic acid and phenol outputs by sheep eating heather and ryegrass}

The voluntary intake of heather by sheep was greatest when $0.2 \mathrm{~kg}$ grass $/ \mathrm{d}$ was offered and decreased as the quantity offered was increased to $0.8 \mathrm{~kg} / \mathrm{d}$ (Table 4 ). There was no relationship between either grass or heather intake and urinary outputs of either benzoic or cinnamic acids; only traces of 3-phenylpropionic acid were excreted. However, urinary phenylacetic acid output was linearly related to the intake of grass by sheep (Fig. 1). The regression equation was significant $(P<0.001)$ and accounted for $80 \%$ of the variance. 
Table 3. Expt 2. Increments in urine phenol output after rumen or abomasum infusion to sheep of $\mathrm{p}$-arbutin, quinol or orcinol

(Mean values with their standard deviations; no. of infusion periods in parentheses)

\begin{tabular}{|c|c|c|c|c|c|c|c|c|}
\hline \multirow{3}{*}{$\begin{array}{l}\text { Phenol } \\
\text { infused }\end{array}$} & \multirow{3}{*}{$\begin{array}{l}\text { Infusion } \\
\text { route }\end{array}$} & \multirow[b]{3}{*}{ Sheep no. } & & & \multicolumn{4}{|c|}{$\begin{array}{l}\text { Percentage of infused phenol } \\
\text { excreted in the urine as: }\end{array}$} \\
\hline & & & \multicolumn{2}{|c|}{ Amount infused $(\mathrm{mg} / \mathrm{d})$} & \multicolumn{2}{|c|}{ Quinol } & \multicolumn{2}{|c|}{ Orcinol } \\
\hline & & & Mean & SD & Mean & $\mathrm{SD}$ & Mean & SD \\
\hline \multirow[t]{10}{*}{ Orcinol } & Rumen & $13,14,15$ & 13 & $10(3)$ & 0 & & 87 & 4 \\
\hline & & $13,14,15$ & 64 & $2(3)$ & 0 & & 79 & 5 \\
\hline & & $13,14,15$ & 130 & $2(3)$ & 0 & & 84 & 5 \\
\hline & & $13,14,15$ & 248 & $4(3)$ & 0 & & 78 & l \\
\hline & Mean rumen & - & - & (12) & 0 & & 82 & 5 \\
\hline & Abomasum & 16 & 12 & (1) & 0 & & 83 & \\
\hline & & 16 & 55 & (1) & 0 & & 71 & \\
\hline & & 16 & 122 & (1) & 0 & & 78 & \\
\hline & & 16 & 228 & (1) & 0 & & 91 & \\
\hline & Mean abomasum & - & - & (4) & 0 & & 81 & 8 \\
\hline & Rumen & $13,14,15$ & 103 & $6(3)$ & 78 & 8 & 0 & \\
\hline \multirow{5}{*}{ Quinol } & Rumen & 13,14 & 132 & (2) & 70 & & 0 & \\
\hline & & $13,14,15$ & 247 & $3(3)$ & 80 & 9 & 0 & \\
\hline & & 13,15 & 510 & (2) & 80 & & 0 & \\
\hline & Mean rumen & - & - & (10) & 77 & 8 & 0 & \\
\hline & Abomasum & 16 & 222 & (1) & 61 & & 0 & \\
\hline
\end{tabular}

Table 4. The voluntary intake of heather by sheep given five levels of grass in relation to outputs of urinary benzoic, 3-phenylpropionic and cinnamic acids

(Mean values with their standard deviations)

\begin{tabular}{|c|c|c|c|c|c|c|c|c|c|c|}
\hline \multicolumn{4}{|c|}{ Food intake $(\mathrm{kg} / \mathrm{d})$} & \multirow{3}{*}{$\begin{array}{l}\text { No. of } \\
\text { sheep }\end{array}$} & \multicolumn{6}{|c|}{$\begin{array}{l}\text { Urinary aromatic acid output } \\
\text { ( } \mathrm{g} \text { benzoic acid equivalent } / \mathrm{d} \text { ) }\end{array}$} \\
\hline \multicolumn{2}{|c|}{ Grass } & \multicolumn{2}{|c|}{ Heather } & & \multicolumn{2}{|c|}{$\begin{array}{l}\text { Benzoic } \\
\text { acid }\end{array}$} & \multicolumn{2}{|c|}{$\begin{array}{l}\text { 3-Phenylpro- } \\
\text { pionic acid }\end{array}$} & \multicolumn{2}{|c|}{ Cinnamic acid } \\
\hline Mean & SD & Mean & so & & Mean & SD & Mean & SD & Mean & SD \\
\hline 0 & & 0.39 & 0.06 & 5 & 5.4 & 1.0 & 0 & & $0 \cdot 10$ & 0.05 \\
\hline 0.21 & 0.01 & 0.48 & 0.01 & 5 & $8 \cdot 1$ & 1.4 & 0 & & 0.06 & 0.03 \\
\hline 0.40 & 0.06 & $0 \cdot 34$ & $0 \cdot 13$ & 5 & 7.7 & $3 \cdot 1$ & 0.01 & 0.02 & 0.09 & 0.04 \\
\hline 0.61 & 0.04 & 0.22 & 0.08 & 5 & $8 \cdot 0$ & $2 \cdot 0$ & 0.02 & 0.03 & $0 \cdot 10$ & 0.03 \\
\hline 0.79 & 0.07 & $0 \cdot 13$ & 0.07 & 4 & $7 \cdot 1$ & $2 \cdot 3$ & 0.01 & 0.02 & 0.06 & 0.02 \\
\hline
\end{tabular}

Urinary phenol output was small $(0-54 \mathrm{mg} / \mathrm{d})$ and more closely related to grass than to heather intake. $p$-Cresol excretion in urine was variable $(386-1145 \mathrm{mg} / \mathrm{d})$ and was not closely related to intake of either heather or grass. Urinary catechol output (32-199 mg/d) increased with increasing total DM intake. 4-Methylcatechol output in urine was not directly related to the individual grass, heather or total DM intakes of the sheep. Mean urinary outputs of these phenols by sheep offered each of the five levels of grass and $a d$ lib. heather are summarized in Table 5. Quinol and orcinol outputs in urine were linearly related to voluntary intakes of heather by sheep (Fig. 2) with none being found in the urine of a sheep 




Fig. 1. The relationship between urinary phenylacetic acid output $(Y)$ and grass dry matter intake $(X)$ of sheep offered one of five levels of grass intake and heather ad lib. $Y=0 \cdot 63 X+0 \cdot 05$.

Table 5. The urinary outputs of phenols $(\mathrm{mg} / \mathrm{d})$ by sheep given one of five levels of grass and heather ad lib.

\begin{tabular}{|c|c|c|c|c|c|c|c|c|}
\hline \multirow{3}{*}{$\begin{array}{c}\text { Nominal } \\
\text { grass intake* } \\
(\mathrm{kg} / \mathrm{d})\end{array}$} & \multicolumn{8}{|c|}{ Urinary output of phenols } \\
\hline & \multicolumn{2}{|c|}{ Phenol } & \multicolumn{2}{|c|}{$p$-Cresol } & \multicolumn{2}{|c|}{ Catechol } & \multicolumn{2}{|c|}{$\begin{array}{l}\text { 4-Methyl- } \\
\text { catechol }\end{array}$} \\
\hline & Mean & SD & Mean & SD & Mean & SD & Mean & so \\
\hline 0 & 4 & 4 & 515 & 105 & 78 & 39 & 115 & 76 \\
\hline $0 \cdot 2$ & 12 & 6 & 818 & 125 & 123 & 32 & 86 & 22 \\
\hline 0.4 & 32 & 8 & 844 & 255 & 145 & 67 & 111 & 135 \\
\hline 0.6 & 27 & 7 & 795 & 230 & 136 & 42 & 69 & 22 \\
\hline $0 \cdot 8$ & 32 & 11 & 648 & 175 & 148 & 53 & 84 & 54 \\
\hline
\end{tabular}

* Mean intakes of dry matter of grass and heather are given in Table 4.

given $0.8 \mathrm{~kg}$ grass only $/ \mathrm{d}$. The linear regressions were significant $(P<0.001)$ and those for quinol and orcinol accounted for 72 and $69 \%$ of the total variance respectively. In Expt 3 all urine phenol assays were made in extracts of acid-hydrolysed urine.

\section{DISCUSSION}

In Expts 1 and 2 urinary outputs of phenol, p-cresol, catechol and 4-methylcatechol in control periods (Table 1) were similar to those previously reported in the urine of sheep (Martin, 1982c) and the proportions of each excreted were similar to those found in sheep urine by Braden et al. (1967) and in the urine of cows by Suemitsu et al. (1970).

Urinary output of $p$-cresol has been found to vary considerably (Table 1). This is no doubt 


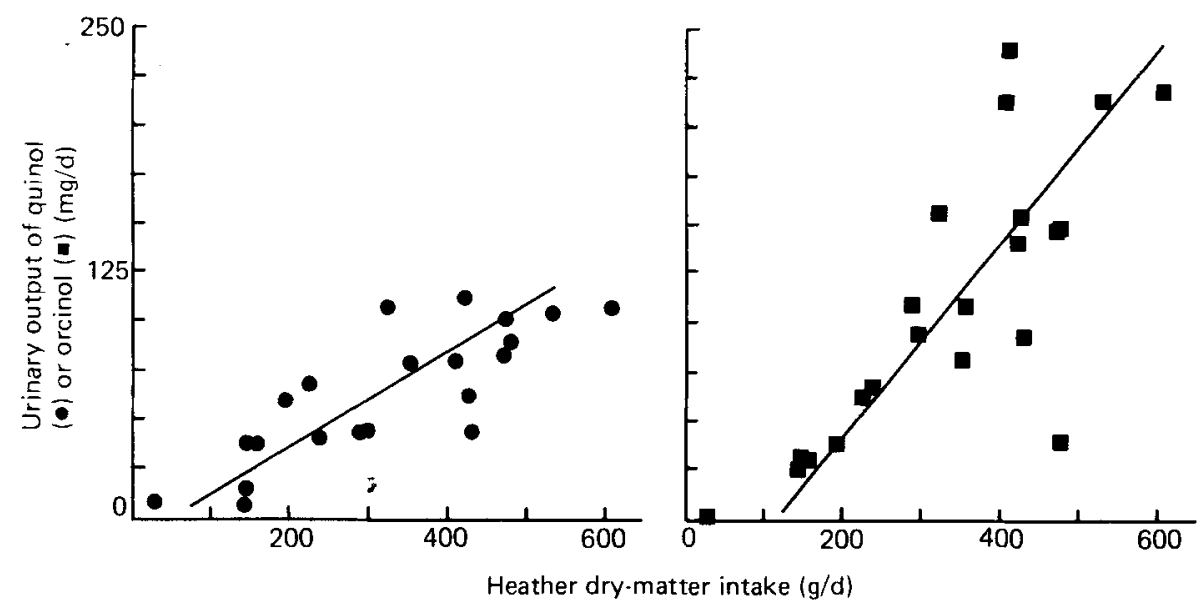

Fig. 2. The linear regressions of urinary outputs $(Y)$ of quinol $(O)$ and orcinol $(\square)$ on the ad lib. heather dry matter intake $(X)$ of sheep offered one of five levels of grass. For quinol the equation was $Y=0 \cdot 25 X-13 \cdot 4$ and for orcinol $Y=0 \cdot 50 X-59 \cdot 7$.

a result of the multiplicity of pathways of microbial metabolism to which its principal precursor, tyrosine, can be subjected in the rumen. Tyrosine can act as either a hydrogen acceptor or donor in a Stickland-type reaction in the rumen to yield respectively 3(4-hydroxyphenyl-)-propionic acid or 4-hydroxyphenylacetic acid (Scott et al. 1964). The former acid is dehydroxylated in the rumen to 3-phenylpropionic acid and excreted as benzoic acid (Martin, 1982 b) and the latter can either be decarboxylated to $p$-cresol (Martin, $1982 c$ ), excreted unchanged or re-utilized for microbial tyrosine synthesis in the rumen (Sauer et al. 1975). In the rabbit approximately $10 \%$ of the $p$-cresol produced is metabolized to $p$-hydroxybenzoic acid in the body tissues (Bray et al. 1950) and a similar reaction occurs in the rat (Bakke, 1970). In Expt 1 almost complete recovery of rumen-administered $p$-cresol was found in the urine (mean \pm SD $94 \pm 10 \%$ ) so body tissue metabolism of $p$-cresol appears to be only slight in sheep. Bray et al. (1950) only recovered $65 \%$ of oral doses of $p$-:resol in the urine of rabbits.

In the present experiments only $55 \pm 9 \%$ (Table 2 ) of rumen-infused catechol were recovered in the urine. Similar percentages of rumen-infused protocatechuic $(3,4-$ dihydroyxybenzoic) and vanillic (3-methoxy-4-hydroxybenzoic) acids were excreted in the urine as catechol after microbial demethylation and decarboxylation (Martin, 1982c). The incomplete recovery of rumen-infused catechol in Expt 1 contrasts with the almost complete urinary recovery $(87-95 \%)$ of catechol obtained following oral doses given to rabbits (Garton \& Williams, 1948; Bray et al. 1952). Phenols can be reductively metabolized in anaerobic environments. Thus, catechol may be converted to cis-benzenediol which is dehydrated to yield phenol, phenol in turn is reduced to cyclohexanol which undergoes ring-fission to yield aliphatic acids (Balba \& Evans, 1980). Such reactions could perhaps explain the low recovery found in Expt 1 although no additional phenol, which is an intermediate in this pathway, was excreted after catechol infusion. However, Simpson et al. (1969) found that anaerobic cultures of rumen micro-organisms were unable to degrade catechol, which may cast doubt upon the ability of unadapted cultures to metabolize significant amounts of catechol by the reductive pathway.

Urine recovery of both rumen- and abomasal-infused quinol was incomplete (Tables 2 and 3). In Expt 1 the apparent incomplete urinary quinol recovery of $68 \pm 15 \%$ is partially 
explained by the enzyme-hydrolysis procedure used; enzyme hydrolysis was later found (A. K. Martin, unpublished observations) to be incapable of completely liberating quinol from the conjugates excreted in sheep urine. In Expt 2 the acid-hydrolysis procedure used would completely liberate quinol from its conjugates in urine. However, on rumen-infusion, recoveries of quinol in urine varied between 70 and $80 \%$ and the limited information available (Table 3 ) on urinary recovery of abomasally-infused quinol did not suggest that microbial metabolism of quinol in the rumen accounted for its incomplete urinary recovery. After rumen infusion of the naturally-occurring quinol $\beta$-glucoside, $p$-arbutin, urinary recovery of the quinol moiety was similar to that found following infusion of quinol itself (Table 3), suggesting that the glucoside was completely hydrolysed. Bray et al. (1952) obtained almost complete urinary recovery of oral doses $(200 \mathrm{mg} / \mathrm{kg})$ of quinol given to rabbits, but Garton \& Williams (1949) obtained recoveries similar to those in the present studies. There were no signs in the present experiments of the dark-coloured oxidation products of free quinol reported by Miller et al. (1973) in the urine of cats following quinol dosage.

Urinary recovery of infused orcinol by sheep was unaffected by the amount infused (12-248 mg/d, Expt 2), the route of administration (rumen or abomasal cannula, Expt 2) or by the quantity of food (which did not contain orcinol precursors) eaten by the sheep (Expt 1). In Expt 1 urinary recovery of infused orcinol was complete $(99 \pm 8 \%$, Table 2$)$. In Expt 2 lower urinary recoveries were obtained $(82 \pm 5 \%$ after rumen infusion and $81 \pm 8 \%$ after abomasal infusion, Table 3). The enzyme hydrolyses used in Expt 2 used less enzyme $(0.5$ i.u. $\beta$-glucuronidase/sample $(5 \mathrm{ml} / \mathrm{l})$ of daily urine output hydrolysed) than was subsequently found to be the optimum amount $(1.25 \mathrm{i}$.u./sample $(5 \mathrm{ml} / \mathrm{l})$ of daily output (A. K. Martin, unpublished observations)). It can be concluded that oral doses of orcinol are virtually quantitatively excreted in the urine of sheep.

Although appreciable amounts of benzoic (Table 4) and phenylacetic acids were excreted by sheep in Expt 3, no relationships were found between intake of heather and urinary outputs of non-phenolic aromatic acids (Table 4). In previous studies (Martin, 1970) the urinary output of benzoic acid by sheep was found to decrease from $16.3 \mathrm{~g}$ benzoic acid $/ \mathrm{kg}$ food eaten per $\mathrm{d}$ with young ryegrass leaf to $5.7 \mathrm{~g}$ benzoic acid $/ \mathrm{kg}$ food eaten per $\mathrm{d}$ with ryegrass straw. When heather alone was eaten in Expt 3 the urinary benzoic acid output $/ \mathrm{kg}$ food eaten per $\mathrm{d}$ was $13.9 \mathrm{~g}$. With increasing grass intake the benzoic acid output, though greater, was not related to total food intake (Table 4). Urinary phenylacetic acid output was, however, related to the intake of grass DM (Fig. 1), confirming previous observations (Martin, 1970) that urinary phenylacetic acid excretion was related to the equilibrium in the rumen between phenylalanine catabolism to phenylacetic acid and its re-utilization by rumen micro-organisms for phenylalanine synthesis (Martin, 1973). Presumably, the tannins in heather prevented any significant degradation of heather proteins by rumen micro-organisms (Milne, 1974).

In Expt 3 the urinary outputs of phenol, $p$-cresol and catechol by sheep on the heather only treatment were smaller than when grass was offered. 4-Methylcatechol, in contrast, was excreted in greater amounts when heather alone was eaten than when grass was offered, but output was variable and showed no significant relationships to food intake (Table 5). Most of the 4-methylcatechol was probably derived from the heather as previous studies in which no heather was offered to sheep resulted in much smaller outputs of this phenol (Martin, 1982c).

Most phenols excreted by sheep are microbial decarboxylation products of 4-hydroxysubstituted benzoic or phenylacetic acids (Martin, 1982c) which either occur as such in the food or are themselves the products of rumen microbial metabolism of other phenolic precursors. It is unusual to find simple phenols in plant foods but some members of the 
Ericaceae do contain $\beta$-glucosides of quinol (Thieme \& Winkler, 1971 $a$ ) and orcinol (Harborne \& Williams, 1969). One object of the present experiments was to see if the phenols present in heather could be used to assess the intake of heather by sheep. The presence of orcinol glycoside in heather has been reported by Brachet (1975) and confirmed in this laboratory. Hydrolysed extracts of leaf tissue of heather harvested at various seasons of the year contained between 0.13 and $0.36 \mathrm{mg}$ orcinol $/ \mathrm{g}$ and 0.02 and $0.08 \mathrm{mg}$ quinol $/ \mathrm{g}$ (A. K. Martin, unpublished work) on a DM basis. Orcinol and orcinol glycoside have also been isolated from soils on which heathers (Erica cinerea L. and Erica umbellata L.) grow (Ballester et al. 1972).

In Expt 3 significant linear regressions $(P<0.001)$ of urinary output of quinol and orcinol on the voluntary intake of heather were obtained (Fig. 2). The orcinol regression showed a large negative intercept on the orcinol axis. An acid-hydrolysis procedure was used in all the phenol assays in this experiment. Although orcinol itself was stable to the acid-hydrolysis conditions used it was subsequently found that up to $75 \%$ greater yields were obtained on enzyme-hydrolysis with $\beta$-glucuronidase-sulphatase preparations (A. K. Martin, unpublished observations). This no doubt was due to the reaction of orcinol in acid conditions with organic compounds such as aromatic aldehydes (Fiegel \& Anger, 1966), ketoses and pentoses (Bailey, 1969) present in the samples.

The $95 \%$ fiducial limits attached to the prediction of the mean voluntary heather intake of sheep from their urinary outputs of quinol and orcinol have been calculated using the regressions obtained. For the mean and maximum urinary quinol outputs of 62 and $113 \mathrm{mg} / \mathrm{d}$, the predicted intakes (mean $\pm \mathrm{SD}$ ) were $308 \pm 36$ and $513 \pm 66 \mathrm{~g} / \mathrm{d}$ respectively. For the mean and maximum urinary orcinol outputs of 93 and $219 \mathrm{mg} / \mathrm{d}$ the predicted intakes (mean $\pm \mathrm{SD}$ ) were $307 \pm 37$ and $561 \pm 81 \mathrm{~g} / \mathrm{d}$ respectively. The errors are larger than desirable and could be reduced by the use of optimum phenol conjugate hydrolysis and extraction procedures (A. K. Martin, unpublished results). The facts that these phenols are quantitatively excreted in urine and that significant $(P<0.001)$ linear regressions were obtained which accounted for 69 (orcinol) and 72 (quinol) \% of the variance suggest that such an approach is capable of producing useful estimates of the voluntary intake of heather by the grazing animal.

To use this technique in practice requires a method for the collection of urine from grazing animals; this has been developed for female sheep by Chambers et al. (1976). It also requires a quantitative assay for quinol and orcinol conjugates in heather and procedures for these assays have been devised (A. K. Martin, unpublished results). As the content of phenols in the leaf and stem-tip tissues is much greater than that in older parts of the plant it is also important to know that the material sampled for phenol assay is that eaten by the sheep. It is also important to know that other phenol-containing plants are not eaten. Although these compounds are unusual in plants there are some plants which contain considerably greater amounts of phenols than are found in heather; thus, the arbutin content of leaf DM in Arctostaphylos uva-ursi (L.) Spreng. may be as much as $155 \mathrm{mg} / \mathrm{g}$ and in Vaccinium vitis-idea L. may reach $75 \mathrm{mg} / \mathrm{g}$ (Thieme \& Winkler, $1971 \mathrm{~b}$ ).

An additional concern must be the potential adaptation of the rumen microflora to degrade quinol or orcinol on long-term exposure to these phenols. Is such adaptation likely in sheep grazing heather moors? This could be studied by determining urinary recovery of quinol and orcinol during infusion experiments lasting several months. However, in those experiments in which adaptation of anaerobic micro-organisms to utilization of the aromatic ring of phenols has been induced, a prolonged period with the phenol substrate as the principal source of organic carbon has usually been required. In the rumen of sheep, quinol and orcinol are only minor components amongst many more readily available organic carbon energy sources. Additionally, on heather moors the proportion of heather 
in the diet is normally low even though the predominant species is heather (Hodgson \& Grant, 1981). It may, therefore, be unlikely that such adaptation would occur. Also, $p$-cresol which is a phenol invariably produced in the rumen as a microbial metabolite of tyrosine (Martin, 1982c) was not found in the present studies to have produced any microbial adaptation to enable it to be utilized as an energy source by the rumen microflora. Phloroglucinol is the only phenol known to undergo rapid ring-fission in the rumen (Simpson et al. 1969); possibly this is due to the facile enol-keto tautomerism shown by this phenol enabling it to react as a triketo derivative.

In this laboratory quinol has only been found in trace amounts (up to $6 \mathrm{mg} / \mathrm{d}$ ) when grass or hay and concentrate foods were offered to sheep (A. K. Martin, unpublished results). Quinol has, however, been found in maize (Zea mays L.) silage (Sakata \& Ishiyama, 1978) although there are no reports of its presence in the unensiled crop. Quinol is produced in the body tissues as an oxidation product of phenol and the extent to which this reaction occurs has been found to vary widely in different species (Capel et al. 1972). In the sheep approximately $16 \%$ of the phenol produced in the rumen on microbial decarboxylation of 4-hydroxybenzoic acid was excreted as quinol (Martin, 1982c). However, the normal phenol output of sheep is small so, unless the urinary phenol output is unusually large, quinol excretion could be used to determine the voluntary intake of heather of known quinol content. Orcinol may, be a more reliable index of heather intake. There is no other known component of the diet which can lead to orcinol production on microbial metabolism in the rumen or on metabolism in the body tissues. Also, orcinol is less prone to oxidation during laboratory manipulations than is quinol.

Quinol and orcinol are useful indices of the voluntary intake of food by ruminants because they are subjected to no metabolic transformation in the animal other than hydrolysis of the plant $\beta$-glucosides in the intestine and conjugation of the absorbed phenol with sulphuric or glucuronic acids in the body tissues. In contrast, urinary phenylacetic acid output depends on a reversible equilibrium between phenylalanine degradation and resynthesis in the rumen. It is unlikely that the relationship between phenylacetic acid excretion and grass intake found in Expt 3 would hold in a grazing situation in which heather and grass would be less likely to be eaten in separate meals. It is likely that the tannins in heather eaten with grass would inhibit the degradation of grass proteins more effectively than when given as separate meals, as in Expt 3, and that a different relationship between grass intake and urinary phenylacetic acid excretion would then be obtained. Heather may also contain some phenolic acids which are not subjected to microbial metabolism in the rumen (Martin, 1982b) and are quantitatively excreted in urine which may be equally good indices of heather intake, but this possibility was not investigated.

The authors are indebted to Mrs J. T. Knox and to Mrs J. Quig for technical assistance. Mr C. Park was in charge of the experimental animals.

\section{REFERENCES}

Bailey, R. W. (1969). In Data for Biochemical Research, 2nd ed., p. 545 [R. M. C. Dawson, D. C. Elliot, W. M. Elliot and K. M. Jones, editors]. Oxford: Clarendon Press.

Bakke, O. M. (1970). Acta pharmac. tox. 28, 28.

Balba, M. T. \& Evans, W. C. (1980). Biochem. Soc. Trans. 8, 452.

Ballester, A., Arines, J. \& Vieitez, E. (1972). Annls Edafologia Agrobiol. 31, 359.

Brachet, J. (1975). Phytochemistry 14, 2727.

Braden, A. W. H., Hart, N. K. \& Lamberton, J. A. (1967). Austr. J. agric. Res. 18, 335.

Bray, H. G., Thorpe, W. V. \& White, K. (1950). Biochem. J. 46, 275.

Bray, H. G., Thorpe, W. V. \& White, K. (1952). Biochem. J. 52, 423.

Capel, I. D., French, M. R., Millburn, P., Smith, R. L. \& Williams, R. T. (1972). Xenobiotica 2, 25.

Chambers, A. R. M., White, I. R., Russell, A. J. F. \& Milne, J. A. (1976). Med. Biol. Eng. 14, 665. 
Clarke, E. C. G. \& Humphreys, D. J. (1971). J. Sci. Fd Agric. 22, 205.

Duran, M. Ketting, D., DeBree, P. K., Van der Heiden, P. K. \& Wadman, S. K. (1973). Clinica chim. Acta 45, 341.

Fiegel, F. \& Anger, V. (1966). Spot Tests in Organic Analysis, 7th ed., p. 204. Amsterdam: Elsevier.

Garton, G. A. \& Williams, R. T. (1948). Biochem. J. 43, 206.

Garton, G. A. \& Williams, R. T. (1949). Biochem. J. 44, 234.

Harborne, J. B. \& Simmonds, N. W. (1964). In Biochemistry of Phenolic Compounds, p. 79 [J. B. Harborne, editor]. London: Academic Press.

Harborne. J. B. \& Williams, C. A. (1969). Phytochemistry 8, 2223.

Hodgson, J. \& Grant, S. A. (1981). In The Effective Use of Forage and Animal Resources in the Hills and Uplands. British Grassland Society Occ. Symp. no. 12, p. 41 [J. Frame, editor]. Hurley: British Grassland Society (Grassland Research Institute).

Kibe, K. \& Kagura, S. (1976). J. Sci. Fd Agric. 27, 726.

Martin, A. K. (1970). Br. J. Nutr. 24, 948.

Martin, A. K. (1973). Br. J. Nutr. 30, 251.

Martin, A. K. (1982a). Br. J. Nutr. 47, 139.

Martin, A. K. (1982b). Br.J. Nutr. 47, 155.

Martin, A. K. (1982c). Br. J. Nutr. 48, 497.

Miller, J. J., Powell, G. M., Olavesen, A. H. \& Curtis, G. C. (1973). Biochem. Soc. Trans, 1, 1163.

Milne, J. A. (1974). J. agric. Sci, Camb. 83, 281.

Sakata, K. \& Ishiyama, S. (1978). J. agric. Chem. Soc. (Japan) 52, 471.

Sauer, F. D., Erfle, J. D. \& Mahadevan, S. (1975). Biochem. J. 150, 357.

Scheline, R. R. (1978). Mammalian Metabolism of Plant Xenobiotics, p. 190. London: Academic Press.

Scott, T. W., Ward, P. F. V. \& Dawson, R. M. C. (1964). Biochem. J. 90, 12.

Simpson, F. J., Jones, G. A. \& Wolin, E. A. (1969). Can. J. Microbiol. 15, 972.

Smith, A. A. (1961). Nature, Lond. 190, 167.

Suemitsu, R., Fujita, S-I., Joshimura, M., Gen, H., Yuasa, A. \& Ushijima, J-I. (1970). Agric. biol. Chem. $34,957$.

Thieme, H. \& Winkler, H-J. (1971 a). Pharmazie 26, 235.

Thieme, H. \& Winkler, H-J. (1971 b). Pharmazie 26, 419.

Tsai, C-G., Gates, D. M., Ingledew, W. M. \& Jones, G. A. (1976). Can. J. Microbiol. 22, 159. 